\title{
Die Wirkung von Nisin auf Clostridium butyricum Prazm.
}

\section{Doctoral Thesis}

Author(s):

Ramseier, Hansruedy

Publication date:

1960

Permanent link:

https://doi.org/10.3929/ethz-a-000087912

Rights / license:

In Copyright - Non-Commercial Use Permitted 


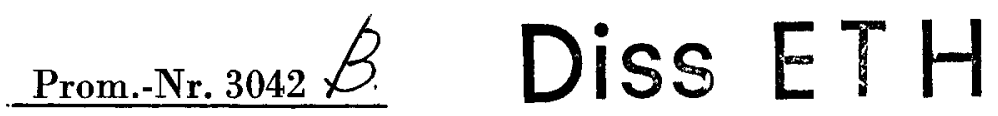

\title{
DIE WIRKUNG VON NISIN AUF
}

CLOSTRIDIUM BUTYRICUM PRAZM.

\author{
Von der \\ EIDGENÖSSISCHEN TEGHNISGHEN \\ HOCHSCHULE IN ZÜRICH \\ zur Erlangung \\ der Würde eines Doktors der \\ technischen Wissenschaften \\ genehmigte \\ PROMOTIONSARBEIT
}

\author{
Vorgelegt von \\ HAN SR UEDY RAM SEIER \\ Dipl. Ing.-Agr. \\ von \\ BASEL UND TRUB (BE)
}

Referent: Herr PROF. DR. E. ZOLLI KOFER

Korreferent: Herr PROF. DR. L. ET T LINGER

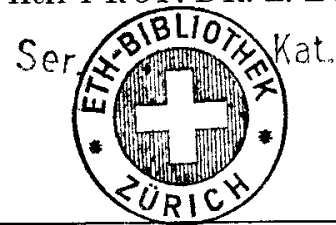

1960 - Wiesbadener Graphische Betriebe GmbH 


\section{Summary}

1. The typical and atypical growth of Clostridium butyricum are described.

2. Nisin, a polypeptide antibiotic produced by certain strains of Streptococcus lactis, has its greatest stability at $\mathrm{p}_{\mathrm{H}} 2$ and appears to be unstable at the conditions of cultivation (EAH-medium $\left[p_{H} 6.5\right], 37^{\circ} \mathrm{C}$.).

3. Spores and vegetative cells of $C l$. butyricum have to be investigated separately, since conventional cultures are not suitable for studying the effect of nisin.

4. Nisin is bactericidal both for young and old vegatative cells. The occurrence of nisin-resistant cells depends upon the age of organisms and the concentration of the antibiotic.

5. Nisin is neither sporostatic nor sporicidal. Germinated spores, on the other hand, are sensitive to the action of nisin.

6. The bactericidal effect of nisin depends upon the size and age of the inoculum the $\mathrm{p}_{\mathrm{H}}$ of the medium, and the medium itself. Vegetative cells and germinated spores absorb nisin strongly. Both the absorption and the bactericidal effect due to bacteriolysis are $\mathrm{p}_{\mathrm{H}}$-dependent, having a maximum at $\mathrm{p}_{\mathrm{H}} 6.5$ to 6.8 . The addition of nisin results in a release of material having an absorption maximum at $260 \mathrm{~m} \mu$. Electron-microscopically the cells appear as empty "ghosts". Nisin resistance of growing vegetative organisms may be increased 32 -fold. This resistance proved to be stable for 31 subcultures. Nisin is neutralized by soap, and bivalent cations reverse the bacteriolytic action of the drug.

7. Nisin acts in a similar manner as cationic detergents and the surface active polypeptide antibiotics. The mode of action of nisin is discussed and compared with that reported for other surface active agents. 
außer Betracht. Die Versuche mit Lipase zeigen, daß bakterielle Lipoide von untergeordneter Bedeutung sind. Es wäre möglich, daß die durch resistente Zellen unseres Organismus aufgenommene achtfach kleinere Nisinmenge (ca. 12\% der durch empfindliche Zellen absorbierten Menge) jener entspricht, die nach Resultaten von NEwTon (1955) bei Polymyxin in der Zellwand grampositiver Organismen festgehalten wird und daß kein Nisin zur cytoplasmatischen Membran gelangen konnte. Die Tatsache, daß sich eine Nisinresistenz nur bei wachsenden Organismen entwickeln konnte, spricht vielleicht dafür, daß solche Zellen eine zur Abschirmung der cytoplasmatischen Membran fähige Substanz synthetisieren können ähnlich den bei Detergentien von BAKER et al. (1941c) vorgeschlagenen Phospholipoiden. Es darf zudem nicht vergessen werden, daß die Nisinabsorption auch der resistenten Zellen relativ groß ist und daß dadurch Nisin quantitativ aus dem System entfernt wird.

Die Unterschiede in der Resistenzerwerbung und im Resistenzgrad scheinen deshalb sowohl auf die Art des oberflächenaktiven Agens als auch auf die unterschiedliche chemische Zusammensetzung und die verschiedenartige Struktur der Zellwände grampositiver und gramnegativer Organismen (SALtoN 1952, 1953, 1956) zurückführbar zu sein.

\section{Zusammenfassung}

1. Es wird das für Clostridium butyricum typische und atypische Wachstum beschrieben.

2. Das von Stämmen von Streptococcus lactis gebildete Polypeptidantibioticum Nisin ist bei $\mathrm{p}_{\mathrm{HF}} 2$ am stabilsten. Die Stabilität des Antibioticums ist unter den angewendeten Kulturbedingungen (EAHMedium $\left[p_{\mathrm{H}} 6,5\right], 37^{\circ} \mathrm{C}$ ) gering.

3. Zur Untersuchung der Wirkung von Nisin auf Cl. butyricum sind konventionelle Kulturen nicht geeignet. Die beiden Entwicklungsformen: Sporen und vegetative Zellen erfuhren eine getrennte Untersuchung.

4. Nisin wirkt sowohl auf junge wie auf alte vegetative Zellen bactericid. Je nach Alter der Organismen und Nisinkonzentration können sich resistente Zellen bilden.

5. Nisin wirkt weder sporostatisch noch sporocid. Dagegen sind gekeimte Sporen nisinempfindlich.

6. Zahlreiche Faktoren, wie Größe und Alter des Inoculums, $\mathrm{p}_{\mathrm{H}}$ des Mediums und das Medium selbst, beeinflussen die bactericide Nisinwirkung. Vegetative Zellen und gekeimte Sporen binden Nisin stark. Sowohl die Nisinabsorption wie auch die infolge der bakteriolytischen Wirkung hervorgerufene Baktericidie sind stark $p_{\mathrm{H}}$-abhängig und besitzen bei $p_{H}$ 6,5 bis 6,8 ein Maximum. Als Folge der bakteriolytischen Wirkung verlieren empfindliche Zellen Material, das ein Absorptions- 
maximum bei $260 \mathrm{~m} \mu$ aufweist, und erscheinen im Elektronenmikroskop als optisch leer. Bei wachsenden vegetativen Organismen kann die Resistenz gegen Nisin um den 32 fachen Betrag erhöht werden. Die Resistenz erwies sich bei einem um das achtfache erhöhten Niveau über 31 Passagen als stabil. Nisin wird durch Seife neutralisiert und zweiwertige Kationen heben die bactericide Wirkung auf.

7. Es wird festgestellt, daß die Wirkung von Nisin manche Ähnlichkeit mit der bei kationaktiven Detergentien und bei anderen Polypeptidantibiotica beschriebenen besitzt, und die bei Nisin gefundenen Ergebnisse werden im Rahmen der bereits bekannten Wirkungsmechanismen diskutiert.

\section{Literatur}

Abraham, E. P.: Biochemistry of some peptide and steroid antibiotics. CIBA Lect. Microbial Biochem. New York: John Wiley and Sons Inc. 1957.

Adams, A. T., J. C. Ayres, R. G. Tischer and B. Ostre: Effect of subtilin on spoilage of thermal processed beef. Food Technol. 6, 421 (1952).

Andersen, A. A.: A rapid plate method for counting spores of Clostridium botulinum. J. Bact. 62, 425 (1951).

ANDERsen, A. A.: Effect of subtilin on spores of Clostridium botulinum. J. Bact. 64, $145(1952)$.

Anderson, H. H., G. G. Villela, E. L. Hansen and R. K. Reed: Some physical and biological properties of subtilin and other antibiotics. Science 103, 419 (1946).

Anker, H. S., B. A. Johnson, J. Goldberg and F. L. Meleney: Bacitracin: Methods of production, concentration, and partial purification, with a summary of the chemical properties of crude bacitracin. J. Bact. 55, 249 (1948).

Baker, Z., R. W. Harrisen and B. F. Miller: Action of synthetic detergents on the metabolism of bacteria. J. exp. Med. 73, 249 (1941 a).

BAKER, Z., R. W. HARRISON and B. F. MILLER: Inhibition by phospholipids of the action of synthetic detergents on bacteria. J. exp. Med. 74, 621 (1941 c).

Bartbo, L. E., and E. M. Foster: Some characteristics of the growth inhibitor produced by a lactic streptococcus. J. Dairy Sci. 34, 1128 (1951).

BeACH, A. S. : An agar diffusion method for the assay of nisin. J. gen. Microbiol. 6, 60 (1952).

Berridge, N. J.: Preparation of the antibiotic nisin. Biochem. J. 45, 486 (1949).

Berridge, N. J.: Counter-current distribution of nisin. Nature (Lond.) 169, 707 (1952).

BerrIDGe, N. J.: The antibiotic nisin and its use in the making and processing of cheese. Chem. and Ind. p. 1158 (1953).

BerRidge, N. J., and J. BARRETT: A rapid method for the turbidimetric assay of antibiotics. J. gen. Microbiol. 6, 14 (1952).

Berridge, N. J., G. G. F. Newron and E. P. Abraham: Purification and nature of the antibiotic nisin. Biochem. J. 52, 529 (1952).

Burss, E. A., C. A. Chandler and E. B. Schoenbach: In vitro studies of polymyxin. Ann. N. Y. Acad. Sci. 51, 944 (1949).

Bricas, E., and C. Fromageot: Naturally occurring peptides. Advanc. Protein Chem. 8, 1 (1953).

Brown, W. L., Z. J. Ordal and H. O. Halvorson: Production and cleaning of spores of Putrefactive Anaerobe 3679. Appl. Microbiol. 5, 156 (1957). 